\title{
EVALUASI LAMA FERMENTASI TERHADAP KARAKTERISTIK BAWANG HITAM MENGGUNAKAN CAMION (BLACK GARLIC FERMENTATION MACHINE)
}

\author{
EVALUATION OF THE BLACK GARLIC FERMENTATION \\ CHRACTERISTIC USING CAMION (BLACK GARLIC \\ FERMENTATION MACHINE)
}

\author{
Melati Ayuning Putri*, Maimunah Hindun Pulungan, Sukardi \\ Jurusan Teknologi Industri Pertanian, Fakultas Teknologi Pertanian, Universitas Brawijaya, Jl. Veteran, Kota \\ Malang, 65145, Indonesia \\ *Email korespondensi: melatiayuputri@gmail.com
}

Diterima 14-09-2020, diperbaiki 27-10-2020, disetujui 13-11-2020

\begin{abstract}
This study was to determine how the effect of fermentation time affected characteristics of black garlic using CAMION with a fermentation period of 10-20 days with an interval of 2 days and a temperature of $70 \pm 1{ }^{\circ} \mathrm{C}$ and a humidity of $70 \pm 1 \%$. The study used a Randomized Block Design (RCBD) with one factor, namely the fermentation time. There were 6 levels used in this study, namely 10 days, 12 days, 14 days, 16 days, 18 days, and 20 days with 3 repetitions. Dependent variables were water content, yield, physical color test, organoleptic, and e-nose. Data were analyzed using Microsoft Office Excel 2010, SPSS, if the significance value was significantly different, then the LSD test was performed at 5\%. Organoleptic data were analyzed using the Friedman test, while electronic nose results were analyzed using the Minitab15 Statistical Software. Based on the results of the study, the fermentation time significantly affected the yield, water content, brightness color $(L)$, reddish color $(a *)$, yellowish color $(b$ *). The fermentation time does not significantly affect the aroma of black onions, but it does have a significant effect on the color, texture, and taste of black onions. The scent that results from the analysis of the electronic nose showed that there was a difference in aroma between CAMION black onions and samples already on the market.
\end{abstract}

Keywords: Black garlic, CAMION, color test, electronic nose, organoleptic

\begin{abstract}
ABSTRAK
Penelitian dilakukan untuk mengevaluasi pengaruh lama fermentasi terhadap karakteristik bawang hitam menggunakan mesin CAMION dengan lama fermentasi $10-20$ hari dan suhu $70 \pm 1^{\circ} \mathrm{C}$ serta kelembaban $70 \pm 1 \%$. Penelitian menggunakan Rancangan Acak Kelompok (RAK) dengan satu faktor yaitu lama fermentasi. Level yang digunakan pada penelitian ada 6 yakni 10 hari, 12 hari, 14 hari, 16 hari, 18 hari, dan 20 hari dengan 3 kali pengulangan. Variabel terikat yang diuji adalah kadar air, rendemen, uji fisik warna, organoleptik, dan aroma dengan e-nose. Data dianalisis menggunakan Microsof Office Excel 2010, SPSS yang apabila nilai signifikansi berbeda nyata maka dilakukan uji BNT 5\%. Data hasil organoleptik dianalisis menggunakan Friedman test, sedangakan data hasil electronic nose dianalisis menggunakan Minitab15 Statistical Software. Berdasarkan hasil penelitian, lama fermentasi berpengaruh nyata terhadap rendemen, kadar air, warna kecerahan $(\mathrm{L})$, warna kemerahan $\left(\mathrm{a}^{*}\right)$, warna kekuningan ( $\left.\mathrm{b}^{*}\right)$. Lama fermentasi tidak berpengaruh nyata terhadap aroma bawang hitam, namun berpengaruh nyata terhadap warna, tekstur, dan rasa bawang hitam. Aroma yang ditimbulkan hasil analisis electronic nose
\end{abstract}


menunjukkan terdapat perbedaan aroma antara bawang hitam hasil fermentasi dengen mesin CAMION dengan sampel yang telah ada dipasaran.

Kata Kunci: Bawang hitam, CAMION, uji fisik warna, electronic nose, organoleptik

\section{PENDAHULUAN}

Bawang putih (Allium sativum L.) ialah tanaman yang banyak tumbuh dan dikonsumsi di Indonesia. Tingkat konsumsi bawang putih dinilai cukup tinggi yakni sebesar 500.000 ton pada tahun 2017 (BPS, 2018) dengan luas panen sebesar $2.146 \mathrm{Ha}$ dan jumlah produksi sebanyak 19.510 ton (BPS, 2019). Bawang putih biasanya digunakan sebagai penyedap rasa, bahan tambahan makanan, dan tanaman obat tradisional karena mengandung senyawa antimikroba seperti triperpenoid, alkaloid, saponin, protein, sterol, dan flavonoid (Safithri, 2004), serta aktivitas antibakteri seperti senyawa allicin (Tsao and Ying, 2001) yang memiliki aktivitas antioksidan yang cukup tinggi (Borlinghaus et al, 2014). Besarnya angka produksi, konsumsi, kandungan, dan pemanfaatan bawang putih yang masih terbatas serta masa simpan yang relatif pendek mendorong masyarakat Indonesia untuk melakukan pengolahan bawang putih menjadi bawang hitam untuk meningkatkan nilai jual.

Menurut Kimura et al (2016) bawang hitam merupakan hasil fermentasi bawang putih pada waktu, suhu, dan kelembaban tertentu. Bawang hitam memiliki rasa manis, bertekstur kenyal, dan berwarna hitam kecoklatan. Bawang hitam banyak digunakan oleh masyarakat untuk obat herbal tradisional karena bawang hitam mengandung aktivitas antioksidan yang lebih tinggi dibandingkan dengan bawang putih. Bawang hitam juga memiliki kandungan antibakteri yang cukup tinggi sehingga dapat menyembuhkan penyakit dengan lebih efektif (Dewi and Wayan, 2018). Proses pembuatan bawang hitam adalah dengan dilakukan fermentasi pada suhu $67^{\circ} \mathrm{C}$ dan kelembaban $90 \%$ dalam waktu \pm 21 sampai 22 hari (Nassur et al,
2017). Penelitian lain yang dilakukan oleh Kimura et al (2016) menyatakan bahwa proses pembuatan bawang hitam dilakukan dengan fermentasi pada suhu $60^{\circ} \mathrm{C}-90^{\circ} \mathrm{C}$ dan kelembaban $80-90 \%$. Proses fermentasi tersebut menyebabkan perubahan warna dari putih menjadi hitam kecoklatan akibat reaksi Mailard yang terjadi. Berdasarkan penelitian lain yang dilakukan Dewi dan Wayan (2018) proses pembuatan bawang hitam dilakukan pada suhu $70^{\circ} \mathrm{C}$ dengan lama fermentasi yang berbeda-beda yakni 30, 40, dan 90 hari. Lama fermentasi menyebabkan produksi bawang hitam menjadi rendah serta dapat mempengaruhi karakteristik bawang hitam yang dihasilkan, sehingga diperlukan inovasi untuk mempercepat proses fermentasi salah satunya dari segi mesin pembuatan bawang hitam yang digunakan.

Proses pembuatan bawang hitam yang relatif lama tersebut, dapat dipercepat menggunakan mesin fermentasi khusus bawang hitam yaitu CAMION (Black Garlic Fermentation Machine). CAMION merupakan mesin fermentasi yang didesain khusus menggunakan teknologi kontrol suhu dan kelembaban sehingga proses fermentasi bawang putih menjadi bawang hitam dapat berjalan secara optimal. CAMION dapat menjaga kestabilan suhu dan kelembaban selama proses fermentasi berlangsung (Nugraha dkk, 2018). Lama fermentasi pada proses pembuatan bawang hitam dapat mempengaruhi karakteristik yang dimiliki oleh bawang hitam itu sendiri. Tujuan dari penelitian ini untuk mengevaluasi lama fermentasi terhadap karakteristik bawang hitam menggunakan mesin CAMION (Black Garlic Fermentation Machine). 


\section{METODE PENELITIAN}

\section{Bahan dan Alat}

Bahan-bahan yang digunakan dalam melaksanakan penelitian ini adalah bawang putih jenis kating. Bawang putih diperoleh dari Pasar Tradisional Sawojajar, Kecamatan Kedungkandang, Kota Malang. Peralatan yang digunakan pada penelitian aini adalah CAMION (Black Garlic Fermentation Machine), moisture analyzer, colorimeter PCE, timbangan digital Sartorius GE2102, wadah, dan electronic nose.

\section{Pelaksanaan Penelitian}

Prosedur yang dilakukan dalam penelitian ini adalah pertama menimbang bawang kating seberat 150 gram, kemudian bawang kating dibungkus menggunakan aluminium foil. Bawang yang telah dibungkus dimasukkan ke dalam plastik tahan panas kemudian di vacuum seal. Selanjutnya mengatur suhu sebesar $70^{\circ} \mathrm{C}$ dengan kelembaban $60 \%$ sampai $70 \%$ pada mesin CAMION. Proses pembuatan bawang hitam menggunakan CAMION dimulai menggunakan lama fermentasi yang telah ditentukan yakni 10 hari, 12 hari, 14 hari, 16 hari, 18 hari, dan 20 hari. Proses pembuatan bawang tersebut diulang sebanyak 3 kali. Setelah bawang hitam jadi sesuai dengan lama fermentasi, dilakukan pengujian yakni uji organoleptik, uji aroma dengan electronic nose, uji kadar air, dan perhitungan rendemen dengan pembandingan berat awal dan akhir. Prosedur terakhir yang dilakukan adalah mencatat dan menghitung hasil pengujian agar diketahui karakteristik dari masingmasing lama fermentasi yang dilakukan.

\section{Variabel yang Diamati}

Rancangan percobaan menggunakan rancangan acak kelompok (RAK) faktorial dengan 1 faktor yakni lama fermentasi sebanyak 3 kali pengulangan. Level yang digunakan pada penelitian ini ada 6 yakni 10 hari, 12 hari, 14 hari, 16 hari, 18 hari, dan 20 hari. Variabel terikat yang diuji adalah kadar air, rendemen, uji fisik warna, organoleptik, dan aroma dengan e-nose. Data yang diperoleh dari uji kadar air dan rendemen dianalisis menggunakan Microsoft Office Excel 2010 yang selanjutnya dianalisis menggunakan Software SPSS untuk mengetahui adanya perbedaan pada setiap perlakuan, apabila nilai signifikansi berbeda nyata maka dilakukan uji lanjutkan BNT 5\%. Hasil uji organoleptik dianalisis menggunakan Friedman test pada Software SPSS, apabila nilai signifikan maka dilanjutkan dengan uji perbandingan berganda untuk mengetahui perbedaan setiap perlakuan. Hasil uji Electronic Nose dianalisis menggunakan Minitab15 Statistical Software untuk mengetahui klasifikasi aroma yang dihasilkan.

\section{HASIL DAN PEMBAHASAN}

\section{Rendemen Bawang Hitam}

Berdasarkan hasil analisis data yang dilakukan, lama fermentasi berpengaruh nyata terhadap rendemen bawang hitam.

Tabel 1 memperlihatkan bahwa semakin lama fermentasi maka rerata rendemen yang diperoleh semakin kecil. Semakin lama proses fermentasi maka kadar air suatu bahan akan semakin berkurang yang berpengaruh terhadap berat suatu bahan tersebut. Berat bahan dipengaruhi salah satunya oleh kadar air yang menguap selama proses fermentasi. Rerata rendemen bawang hitam dapat dilihat pada Tabel 1 .

Tabel 1. Rerata Rendemen Bawang Hitam pada Berbagai Lama Fermentasi

\begin{tabular}{ccccc}
\hline $\begin{array}{c}\text { Lama } \\
\begin{array}{c}\text { Fermen } \\
\text { tasi } \\
\text { (hari) }\end{array}\end{array}$ & $\begin{array}{c}\text { Rerata } \\
\text { rendemen } \\
(\%)\end{array}$ & $\begin{array}{c}\text { Standar } \\
\text { deviasi }\end{array}$ & $\begin{array}{c}\text { BNT } \\
(5 \%)\end{array}$ & Notasi \\
\hline 10 & 84.68 & 0.07 & & $\mathrm{~d}$ \\
12 & 82.70 & 0.06 & & $\mathrm{~cd}$ \\
14 & 80.50 & 0.04 & 0.040 & $\mathrm{c}$ \\
16 & 74.41 & 0.02 & 915 & $\mathrm{~b}$ \\
18 & 71.34 & 0.01 & & $\mathrm{~b}$ \\
20 & 64.18 & 0.04 & & $\mathrm{a}$ \\
\hline
\end{tabular}


Ketika suatu bahan mengalami fermentasi, maka kadar air dalam bahan mengalami penguapan seiring dengan lama proses yang digunakan, sehingga rendemen yang dihasilkan juga akan semakin berkurang. Sesuai dengan pendapat Djonny (2018) yang menyatakan bahwa semakin lama proses fermentasi maka nilai rendemen yang diperoleh semakin berkurang. Proses fermentasi menyebabkan adanya perombakan glukosa yang terjadi sehingga rendemen menjadi berkurang (Widianto dkk, 2013).

\section{Kadar Air Bawang Hitam}

Berdasarkan hasil analisis data yang dilakukan, lama fermentasi berpengaruh nyata terhadap kadar air bawang hitam. Rerata kadar air bawang hitam dapat dilihat pada Tabel 2.

Tabel 2. Rerata Kadar Air Bawang Hitam pada Berbagai Lama Fermentasi

\begin{tabular}{ccccc}
\hline $\begin{array}{c}\text { Lama } \\
\begin{array}{c}\text { Fermenta } \\
\text { si (hari) }\end{array}\end{array}$ & $\begin{array}{c}\text { Rerata } \\
\text { kadar } \\
\text { air } \\
(\%)\end{array}$ & $\begin{array}{c}\text { Standar } \\
\text { deviasi }\end{array}$ & $\begin{array}{c}\text { BNT } \\
(5 \%)\end{array}$ & $\begin{array}{c}\text { Nota- } \\
\text { si }\end{array}$ \\
\hline 10 & 52,59 & 0,011055 & & $\mathrm{f}$ \\
12 & 42,06 & 0,001234 & & $\mathrm{e}$ \\
14 & 33,63 & 0,004015 & 0,006 & $\mathrm{~d}$ \\
16 & 26,92 & 0,005005 & 6041 & $\mathrm{c}$ \\
18 & 22,01 & 0,006005 & & $\mathrm{~b}$ \\
20 & 20,27 & 0,002631 & & $\mathrm{a}$ \\
\hline
\end{tabular}

Tabel 2 memperlihatkan bahwa semakin lama fermentasi maka rerata kadar air yang diperoleh semakin kecil. Hal tersebut diduga terjadi karena penguapan air selama fermentasi berlangsung. Proses fermentasi dengan suhu tinggi dan waktu yang lama menyebabkan kadar air dalam bahan mengalami penguapan akibat energi panas yang dihasilkan. Penguapan tersebut dipengaruhi oleh adanya suhu tinggi dan lama fermentasi. Menurut Zhafira (2018) semakin lama fermentasi menyebabkan massa air yang terdapat dalam bahan ikut menguap sehingga kadar air semakin menurun. Zhang et al (2015) juga menyatakan bahwa dengan meningkatnya lama fermentasi yang dilakukan, maka kadar air pada bawang hitam juga akan berkurang.

\section{Uji Fisik Warna (L, a, b)}

Pengukuran warna dilakukan menggunakan colorimeter dengan tiga hasil pengukuran yaitu nilai $L$, $a$, dan $b$. Nilai $L$ merupakan parameter kecerahan dengan warna kromatik 0 adalah hitam sampai 100 adalah putih. Nilai a menunjukkan adanya warna kromatik campuran warna merah dan hijau dengan nilai a+ yakni $0-100$ berwarna merah dan a- yakni 0-(-80) berwarna hijau. Nilai b menunjukkan warna kromatik campuran warna biru dan kuning dengan nilai $b+$ yakni 0-70 yakni berwarna kuning dan b- yakni 0-(-70) berwarna biru (Engelen, 2018). Sampel yang digunakan pada pengujian warna ini berjumlah 9 sampel yang terdiri dari perlakuan hari ke$0,3,5,10,12,14,16,18$, dan 20.

\section{Kecerahan Warna (L)}

Berdasarkan hasil analisis data yang dilakukan, lama fermentasi berpengaruh nyata terhadap warna kecerahan (L) bawang hitam. Rerata pengukuran warna kecerahan (L) bawang hitam dapat dilihat pada Tabel 3.

Tabel 3. Rerata Pengukuran Kecerahan Warna (L) Bawang Hitam pada Berbagai Lama Fermentasi

\begin{tabular}{ccc}
\hline $\begin{array}{c}\text { Lama } \\
\text { Fermentasi } \\
\text { (hari) }\end{array}$ & $\begin{array}{c}\text { Rerata } \\
\text { Kecerahan } \\
\text { Warna (L) }\end{array}$ & $\begin{array}{c}\text { Standar } \\
\text { Deviasi }\end{array}$ \\
\hline 0 & 82.65 & 2.20 \\
3 & 51.08 & 0.37 \\
5 & 41.21 & 1.00 \\
10 & 37.78 & 0.34 \\
12 & 24.71 & 0.57 \\
14 & 23.71 & 0.10 \\
16 & 21.65 & 0.92 \\
18 & 19.63 & 0.31 \\
20 & 19.10 & 0.07 \\
\hline
\end{tabular}

Pada Tabel 3 dapat dilihat bahwa hasil pengukuran kecerahan warna (L) semakin menurun, sehingga dapat dikatakan bahwa semakin lama waktu 
fermentasi maka warna bawang menjadi semakin hitam. Rerata warna kecerahan tertinggi terdapat pada fermentasi hari ke- 0 karena warna bawang putih masih belum mengalami perubahan, sedangkan rerata warna kecerahan terendah terdapat pada fermentasi hari ke-20 karena warna bawang putih sepenuhnya telah berubah menjadi hitam. Menurut Indiarto dkk (2012) semakin tinggi nilai L maka semakin putih warna produk tersebut. Perubahan warna diakibatkan reaksi Mailard yang terjadi selama proses fermentasi (Choi et al, 2014). Reaksi Maillard dapat menghasilkan bahan berwarna coklat akibat terbentuknya senyawa melanoidin yang mempengaruhi warna kecerahan pada suatu bahan (Anggraeni dkk, 2017). Semakin lama waktu yang fermentasi maka semakin gelap warna yang dihasilkan (Miladulhaq, 2018).

\section{Warna Kemerahan (a*)}

Berdasarkan hasil analisis data yang dilakukan, lama fermentasi berpengaruh nyata terhadap warna kemerahan $\left(a^{*}\right)$ bawang hitam. Rerata pengukuran nilai ( $\left.\mathrm{a}^{*}\right)$ bawang hitam dapat dilihat pada Tabel 4.

Tabel 4. Rerata Pengukuran Warna Kemerahan (a*) Bawang Hitam pada Berbagai Lama Fermentasi

\begin{tabular}{ccc}
\hline $\begin{array}{c}\text { Lama } \\
\text { Fermentasi } \\
\text { (hari) }\end{array}$ & $\begin{array}{c}\text { Rerata Warna } \\
\text { Kemerahan }\end{array}$ & $\begin{array}{c}\text { Standar } \\
\text { Deviasi }\end{array}$ \\
\hline 0 & 2.54 & 0.02 \\
3 & 12.14 & 0.22 \\
5 & 9.02 & 0.56 \\
10 & 9.53 & 0.03 \\
12 & 9.11 & 0.13 \\
14 & 2.42 & 0.50 \\
16 & 5.28 & 0.14 \\
18 & 6.33 & 0.26 \\
20 & 5.14 & 0.03 \\
\hline
\end{tabular}

Pada Tabel 4 dapat dilihat bahwa hasil pengukuran warna kemerahan $\left(\mathrm{a}^{*}\right)$ semakin lama fermentasi cenderung semakin menurun. Menurut Choi et al. (2014) warna kemerahan pada bawang hitam meningkat seiring dengan semakin lama fermentasi yang dilakukan, sedangkan warna kecerahan dan warna kekuningan akan menurun selama proses fermentasi. Perbedaan hasil pengukuran warna kemerahan yang dilakukan dengan literatur diduga dipengaruhi oleh cahaya lingkungan pada saat dilakukan pengujian, sehingga data menjadi bias dan mengakibatkan penurunan nilai kemerahan. Pada Tabel 4 juga terlihat bahwa pada lama fermentasi hari ke-3 memiliki rerata warna kemerahan tertinggi. Hal ini diduga disebabkan oleh adanya kesalahan pada saat dilakukan pengujian warna. Perubahan warna kemerahan yang terjadi pada setiap lama fermentasi terjadi akibat adanya reaksi Maillard, dimana reaksi ini menyebabkan gula yang terdapat pada bahan melebihi titik lebur sehingga memberikan warna kecoklatan atau kemerahan (Nilasari dkk, 2017).

\section{Warna Kekuningan (b*)}

Berdasarkan hasil analisis data yang dilakukan, lama fermentasi berpengaruh nyata terhadap warna kekuningan $\left(b^{*}\right)$ bawang hitam. Rerata pengukuran warna kekuningan $\left(b^{*}\right)$ bawang hitam dapat dilihat pada Tabel 5.

Tabel 5. Rerata Pengukuran Warna Kekuningan (b*) Bawang Hitam pada Berbagai Lama Fermentasi

\begin{tabular}{ccc}
\hline $\begin{array}{c}\text { Lama } \\
\text { fermentasi } \\
\text { (hari) }\end{array}$ & $\begin{array}{c}\text { Rerata Warna } \\
\text { Kekuningan }\end{array}$ & $\begin{array}{c}\text { Standar } \\
\text { Deviasi }\end{array}$ \\
\hline 0 & 18.74 & 1.19 \\
3 & 22.93 & 0.36 \\
5 & 9.12 & 1.82 \\
10 & 8.92 & 0.36 \\
12 & 7.03 & 0.38 \\
14 & 0.83 & 0.29 \\
16 & 2.77 & 0.77 \\
18 & 2.57 & 0.83 \\
20 & 2.20 & 0.44 \\
\hline
\end{tabular}

Pada Tabel 5 dapat dilihat bahwa hasil pengukuran warna kekuningan $\left(b^{*}\right)$ semakin lama cenderung semakin menurun. Hal ini diduga karena adanya reaksi Maillard yang terjadi pada bawang putih. 
Lama fermentasi yang dilakukan berpengaruh terhadap pengurangan dan fragmentasi glukosa, serta terjadinya degradasi asam amino, sehingga warna kekuningan semakin lama akan semakin menurun (Choi et al, 2014). Reaksi Maillard menyebabkan terbentuknya warna kecoklatan atau melanoidin. Semakin lama proses fermentasi maka warna kekuningan akan semakin rendah (Nilasari dkk, 2017). Hal ini juga sesuai dengan pendapat (Zhafira, 2018) yang menyatakan tingkat warna kekuningan akan menurun seiring dengan menurunnya tingkat kecerahan.

\section{Electronic Nose Bawang Hitam}

Pengujian aroma dengan $e$-nose yang dilakukan menggunakan 2 sampel yakni perlakuan terbaik hasil organoleptik bawang hitam dan bawang hitam yang telah ada dipasaran. Grafik hasil analisis aroma dengan $e$-nose dapat dilihat pada Gambar 1 dan Gambar 2.

Hasil analisa data pada Gambar 1 dan Gambar 2 diperoleh hasil terdapat 10 garis yang menunjukkan masing-masing sensor pada $e$-nose yakni garis $\mathrm{C} 1$ sampai $\mathrm{C} 1$.

Garis terpanjang menunjukkan bahwa sensor tersebut memiliki kepekaan yang paling tinggi dibandingkan sensor yang lain. Garis C1 sampai C10 kemudian diurutkan berdasarkan peringkat untuk mengetahui aroma yang paling dominan yang dikeluarkan oleh masing-masing sampel saat dilakukan pengujian. Hasil pemeringkatan aroma pada electronic nose dapat dilihat pada Tabel 6. Grafik laba-laba pemeringkatan aroma pada electronic nose dapat dilihat pada Gambar 3 dan Gambar 4.

Tabel 6. Hasil Peringkat Aroma Electronic Nose

\begin{tabular}{|c|c|c|c|c|}
\hline \multirow{2}{*}{ Peringkat } & \multicolumn{4}{|c|}{ Sampel } \\
\hline & CAMION & Aroma & UKM & Aroma \\
\hline 1 & MQ-4 & Gas alam dan Metan & MQ-7 & $\begin{array}{l}\text { Gas Karbon } \\
\text { Monoksida }\end{array}$ \\
\hline 2 & MQ-6 & LPG dan Propane & MQ-136 & $\begin{array}{l}\text { Gas Hidrogen } \\
\text { Sulfida }\end{array}$ \\
\hline 3 & MQ-2 & Gas Combustible & MQ-6 & LPG dan Propane \\
\hline 4 & MQ-7 & $\begin{array}{l}\text { Gas Karbon } \\
\text { Monoksida }\end{array}$ & MQ-2 & Gas Combustible \\
\hline 5 & MQ-9 & $\begin{array}{l}\text { Gas Karbon } \\
\text { Monoksida dan } \\
\text { Combustile Gas }\end{array}$ & MQ-4 & $\begin{array}{l}\text { Gas alam dan } \\
\text { Metan }\end{array}$ \\
\hline 6 & MQ-135 & $\begin{array}{c}\text { Kontrol Kualitas } \\
\text { Udara }\end{array}$ & MQ-3 & Alkohol \\
\hline 7 & MQ-136 & $\begin{array}{l}\text { Gas Hidrogen } \\
\text { Sulfida }\end{array}$ & MQ-135 & $\begin{array}{c}\text { Kontrol Kualitas } \\
\text { Udara }\end{array}$ \\
\hline 8 & MQ-5 & $\begin{array}{l}\text { LPG, Gas Alam, dan } \\
\text { Gas Batu Bara }\end{array}$ & MQ-8 & Gas Hidrogen \\
\hline 9 & MQ-8 & Gas Hidrogen & MQ-5 & $\begin{array}{l}\text { LPG, Gas Alam, } \\
\text { dan Gas Batu Bara }\end{array}$ \\
\hline 10 & MQ-3 & Alkohol & MQ-9 & $\begin{array}{l}\text { Gas Karbon } \\
\text { Monoksida dan } \\
\text { Combustile Gas }\end{array}$ \\
\hline
\end{tabular}




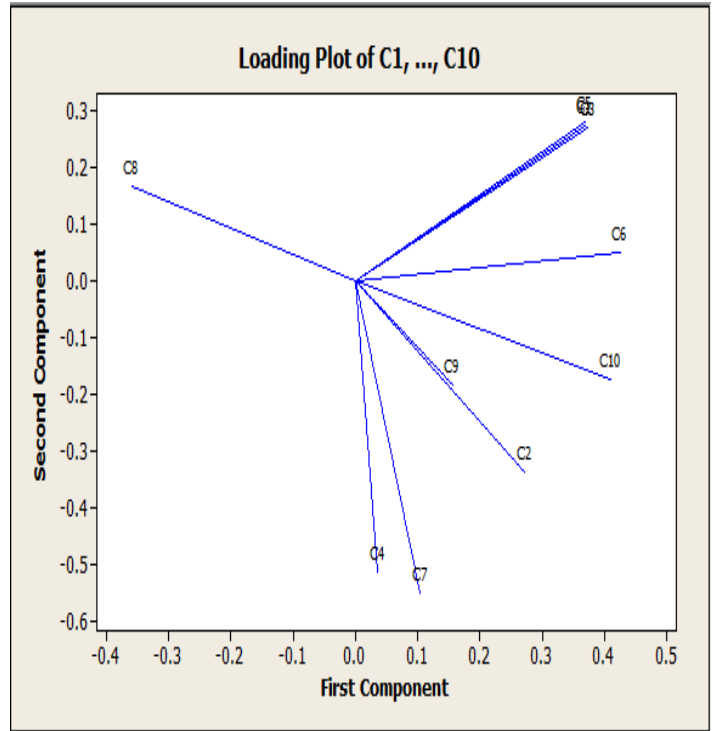

Gambar 1. Grafik Sampel CAMION

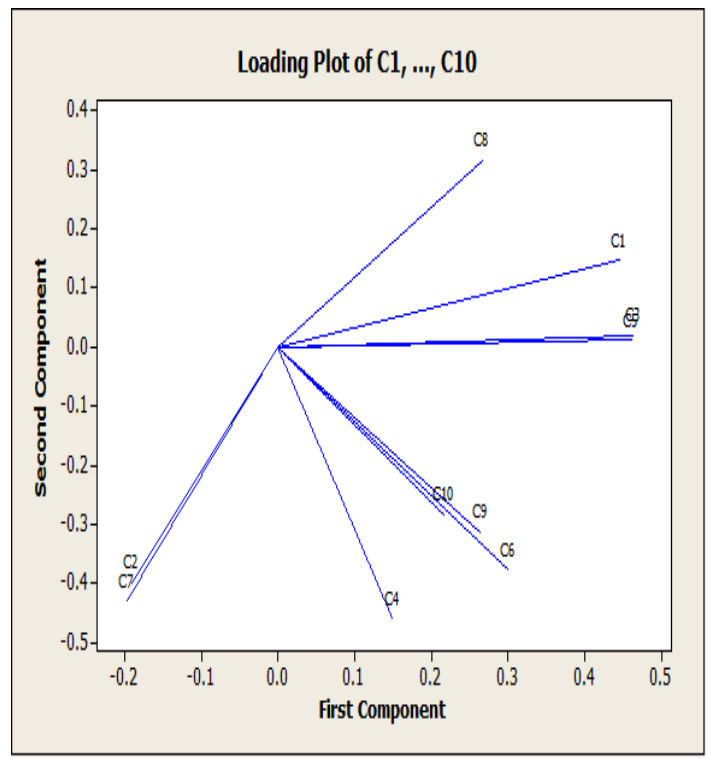

Gambar 2. Grafik Sampel UKM

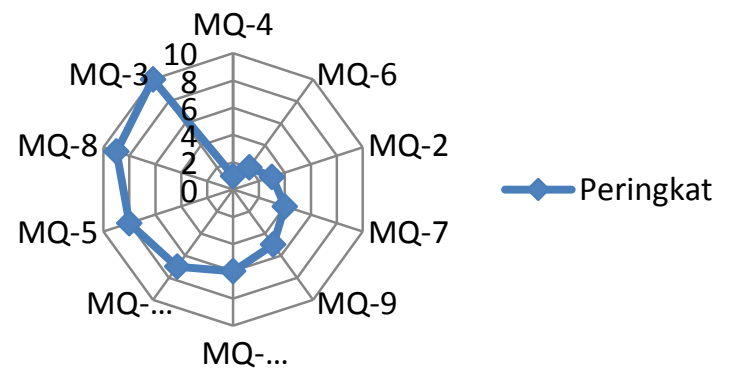

Gambar 3. Grafik laba-laba Sampel CAMION

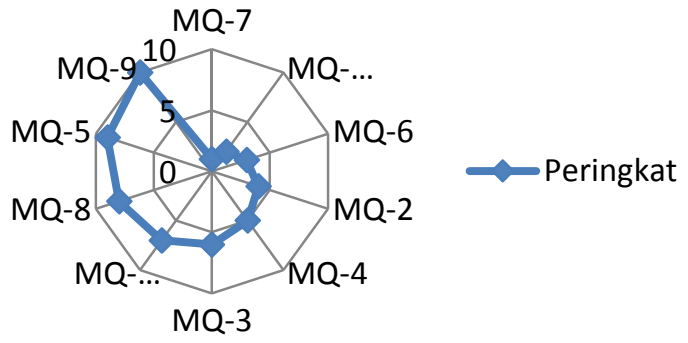

Gambar 4. Grafik laba-laba Sampel UKM

Pada pemeringkatan yang telah dilakukan diperoleh hasil terdapat perbedaan aroma yang ditimbulkan pada kedua sampel. Peringkat satu pada sampel CAMION yakni sensor MQ-4 yang peka terhadap gas alam dan metan, sedangkan peringkat 1 pada sampel UKM yakni sensor MQ-7 yang peka terhadap gas karbon monoksida. Perbedaan tersebut diduga terjadi karena perbedaan lama waktu fermentasi dan alat yang digunakan pada proses pembuatan antara kedua sampel. Lama fermentasi sampel CAMION membutuhkan waktu 20 hari, sedangkan lama fermentasi sampel UKM membutuhkan waktu 25 hari. Alat yang digunakan pada proses pembuatan sampel penelitian adalah CAMION (Black Garlic Fermentation Machine), sedangkan alat yang digunakan pada sampel UKM adalah Magicom. Menurut Zhang et al (2015) proses fermentasi yang dialami bawang hitam menurunkan aroma menyengat yang sebelumnya terdapat pada bawang putih. Aroma menyengat tersebut disebabkan oleh kandungan Allin yang dimiliki bawang putih dan ketika mengalami pemanasan, Allin mengalami dekomposisi dan berubah menjadi allyl sulfur yang menyebabkan aroma menyengat menjadi sangat berkurang. Perbedaan ini juga terjadi akibat adanya perubahan senyawa-senyawa sulfur yang terjadi selama proses fermentasi. Lamanya fermentasi berpengaruh terhadap reaksi yang terjadi di dalam bawang hitam 
yang mengakibatkan senyawa sulfur dapat dengan mudah berubah menjadi senyawa volatile (Abe et al, 2020). Suhu tinggi yang digunakan pada proses fermentasi juga mempengaruhi perbedaan aroma yang dihasilkan dari kedua sampel.

\section{Organoleptik Aroma Bawang Hitam}

Berdasarkan hasil analisis data, lama fermentasi tidak berpengaruh nyata terhadap organoleptik aroma bawang hitam. Grafik yang dihasilkan cenderung stabil karena memiliki rerata yang hampir sama. Rerata hasil organoleptik aroma bawang hitam dapat dilihat pada Gambar 5.

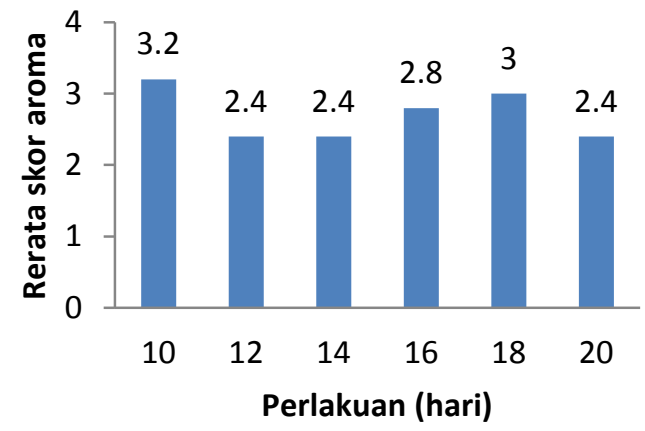

Gambar 5. Rerata Skor Aroma Bawang
Hitam pada Berbagai
Perlakuan Fermentasi (hari)

Gambar 5 menunjukkan bahwa terjadi perbedaan skor aroma yang diberikan panelis terhadap setiap perlakuan. Perbedaan skor tersebut dipengaruhi oleh lama fermentasi yang terjadi pada setiap perlakuan. Menurut Nelwida dkk (2019) bawang hitam memiliki warna yang hitam dengan tekstur lembut dan rasa manis serta tidak mengeluarkan aroma yang menyengat. Perubahan aroma pada setiap perlakuan juga terjadi akibat berubahnya senyawa allicin selama proses fermentasi. Senyawa allicin merupakan senyawa yang sangat berpengaruh terhadap pembentukan aroma bawang putih, sehingga saat bawang putih mengalami proses fermentasi senyawa allicin berubah menjadi senyawasenyawa antara lain S-Allylcysteine, tetrahydro- $\beta$-carbolines, biologically active alkaloids, and flavonoid-like compounds dimana senyawa ini berperan bersar dalam aktivitas antioksidan bawang hitam, sehingga berakibat pada berkurangnya aroma menyengat pada bawang hitam (Choi et al, 2014). Selama terjadi proses fermentasi Allin dan Allicin berubah menjadi senyawa yang lebih stabil yang menyebabkan aroma dan juga rasa bawang hitam menjadi berubah (Zhang et al, 2015).

\section{Organoleptik Warna Bawang Hitam}

Berdasarkan hasil analisis data, lama fermentasi berpengaruh nyata terhadap organoleptik warna bawang hitam. Rerata hasil organoleptik warna bawang hitam dapat dilihat pada Gambar 6.

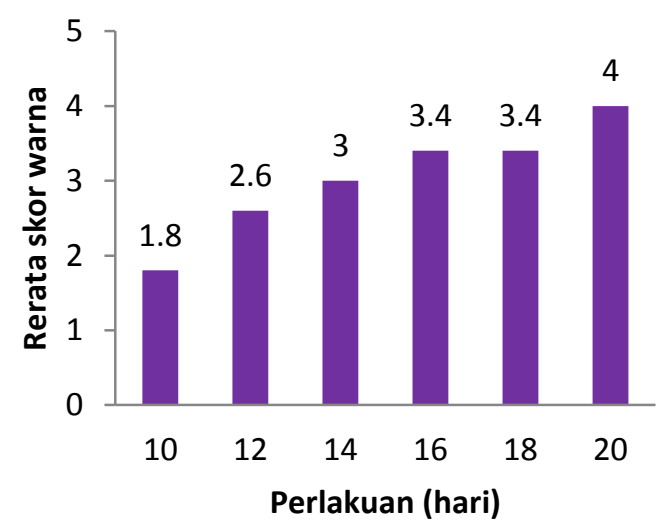

Gambar 6. Rerata Skor Warna Bawang Hitam pada Berbagai Perlakuan Fermentasi (hari)

Gambar 6 menunjukkan bahwa semakin lama fermentasi yang dilakukan maka skor organoleptik warna yang diperoleh semakin tinggi. Peningkatan skor tersebut berarti bahwa warna yang dihasilkan semakin hitam seiring dengan semakin lama fermentasi yang dilakukan. Perubahan warna tersebut akibat reaksi Maillard yang terjadi selama proses fermentasi. Menurut Handayani dkk (2018) reaksi Maillard yang terjadi akibat proses aging dapat menyebabkan berubahnya warna pada bawang hitam. Reaksi Maillard merupakan reaksi yang terjadi antara gula pereduksi dengan komponen amino karena perubahan suhu dan kadar air yang cepat. 
Reaksi Maillard dapat menyebabkan suatu bahan berubah warna menjadi coklat, sehingga semakin lama fermentasi atau pemanasan maka semakin pekat tingkat kecoklatan suatu bahan tersebut (Miladulhaq, 2018). Perubahan warna pada bawang hitam juga berhubungan dengan konstanta Michaelis Menten. Persamaan Michaelis Menten menyebutkan bahwa semakin tinggi konstrasi substrat maka semakin cepat terjadi reaksi enzim sehingga mencapai kecepatan yang tetap. Semakin lama fermentasi yang dilakukan maka konsentrasi substrat $\gamma$-Glutamyl-Sallyl cysteine akan semakin tinggi sehingga mengakibatkan reaksi enzim $\gamma^{-}$ Glutamyltranspeptidase akan semakin cepat (Lund and Colin, 2017). Reaksi ini menyebabkan terjadinya peningkatan kecepatan pembentukan S-allyl cysteine yang berdampak pada reaksi Mailard. Sehingga reaksi Mailard dapat berjalan lebih cepat dan mengakibatkan perubahan warna pada bawang hitam menjadi semakin gelap.

\section{Organoleptik Tekstur Bawang Hitam}

Berdasarkan hasil analisis data, lama fermentasi berpengaruh nyata terhadap organoleptik tekstur bawang hitam. Rerata hasil organoleptik tekstur bawang hitam dapat dilihat pada Gambar 7.

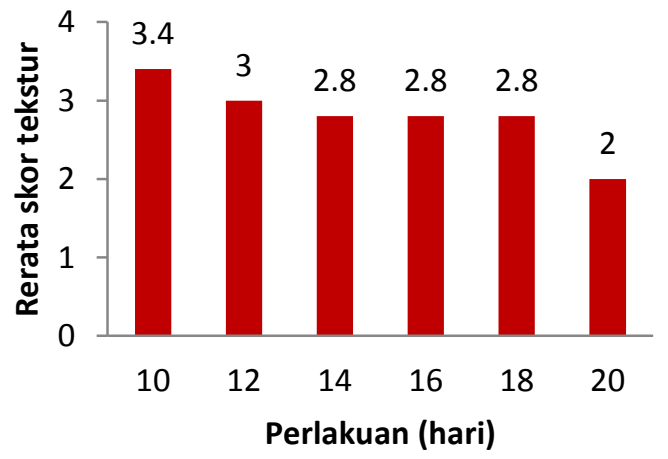

Gambar 7. Rerata Skor Tekstur Bawang Hitam pada Berbagai Perlakuan Fermentasi (hari)
Gambar 7 menunjukkan bahwa skor organoleptik semakin lama fermentasi maka tekstur yang diperoleh cenderung semakin menurun yang berarti semakin tidak kenyal atau lunak. Perubahan tekstur dari bawang putih yang keras menjadi bawang hitam yang lunak terjadi akibat bawang hitam mengalami fermentasi dengan suhu dan kelembaban yang tinggi. Semakin lama fermentasi maka kelembaban pada bahan akan semakin meningkat. Menurut (Sun and Weidong, 2018) kelembaban optimal yang digunakan saat proses fermentasi bawang hitam adalah $85 \%$ dengan suhu $75^{\circ} \mathrm{C}$. Tekstur yang semakin melunak ini juga terjadi akibat kadar air dalam bahan yang semakin berkurang namun memiliki tingkat kelembaban yang tinggi. Penelitian yang dilakukan oleh Kang (2016) menyatakan bahwa tekstur bawang hitam akan menurun seiring dengan lama fermentasi yang digunakan, hal tersebut terjadi karena tingginya kelembaban dan menurunnya kadar air selama proses fermentasi. Kandungan pati yang terdapat pada bawang putih akan menurun seiring dengan semakin lama fermentasi yang dilakukan. Penurunan kandungan pati ini berdampak pada peningkatan kandungan gula yang terdapat dalalm bawang hitam, sehingga semakin lama fermentasi yang dilakukan bawang hitam akan semakin melunak (Arifiya dkk, 2015).

\section{Organoleptik Rasa Bawang Hitam}

Berdasarkan hasil analisis data, lama fermentasi berpengaruh nyata terhadap organoleptik rasa bawang hitam. Rerata hasil organoleptik rasa bawang hitam dapat dilihat pada Gambar 8. 


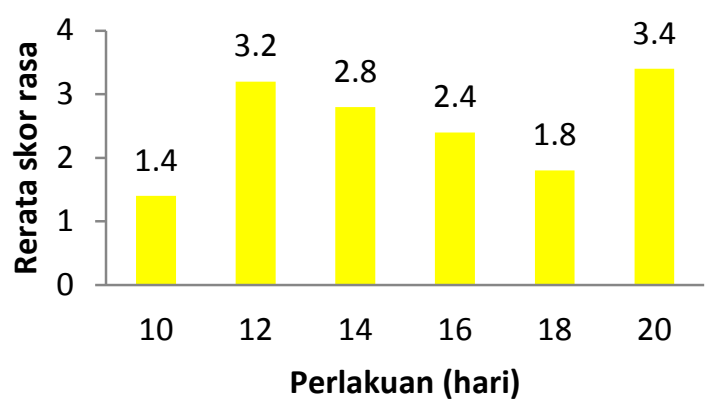

Gambar 8. Rerata Skor Rasa Bawang Hitam pada Berbagai Perlakuan Fermentasi (hari)

Gambar 8 menunjukkan bahwa terjadi perubahan rasa pada setiap perlakuan yang dilakukan dari sangat tidak manis sampai manis. Perubahan rasa tersebut terjadi akibat adanya perubahan senyawa-senyawa selama proses fermentasi. Salah satu senyawa yang berpengaruh terhadap perubahan rasa pada bawang hitam adalah allicin. Menurut Kimura et al (2016) senyawa allicin berperan dalam pembentukan rasa dan aroma pada bawang putih. Perubahan rasa bawang putih yang sengir menjadi bawang hitam yang manis juga diakibatkan adanya reaksi Maillard yang terjadi selama proses fermentasi. Menurut Yuan et al (2016) selama proses fermentasi, fruktan yang terdapat pada bawang putih berubah menjadi fruktosa dan glukosa, gula yang larut dalam air mengalami peningkatan sebesar $187,79 \%$ sampai $790,95 \%$. Hal inilah yang menyebabkan bawang hitam memiliki rasa yang manis. Rasa manis yang ditimbulkan bawang hitam akan maksimal jika suhu fermentasi yang digunakan yakni antara $60^{\circ} \mathrm{C}$ sampai $70^{\circ} \mathrm{C}$ (Kimura et al, 2016).

\section{KESIMPULAN}

\section{Kesimpulan}

Hasil penelitian dapat disimpulkan bahwa lama fermentasi berpengaruh nyata terhadap rendemen, kadar air, warna kecerahan, warna kemerahan, warna kekuningan bawang hitam. Lama fermentasi juga berpengaruh nyata pada organoleptik bawang hitam seperti warna, tekstur, dan rasa, namun tidak berpengaruh nyata pada aroma bawang hitam. Semakin lama fermentasi maka nilai rendemen dan kadar air akan semakin menurun. Semakin lama fermentasi maka rata-rata nilai pengukuran warna kecerahan, warna kemerahan, dan warna kekuningan cenderung semakin kecil. Hasil uji aroma electronic nose menunjukkan bahwa terdapat perbedaan aroma yang ditimbulkan antara bawang hitam sampel CAMION dengan sampel yang sudah ada dipasaran. Hasil uji organoleptik semakin lama fermentasi maka warna bawang yang dihasilkan semakin hitam, tekstur semakin tidak kenyal atau lunak, dan rasa cenderung lebih manis. Aroma bawang hitam stabil dari perlakuan hari ke-10 sampai 20 yakni tidak menyengat.

\section{Saran}

Perlu dilakukan penelitian mengenai perbaikan mesin CAMION agar kondisi ruang fermentasi menjadi lebih vakum. Perlu dilakukan penelitian mengenai penggunaan bawang putih jenis lain dengan menggunkan CAMION. Perlu juga dilakukan penelitian tentang penerimaan hasil bawang hitam CAMION kepada masyarakat dibandingkan dengan produk yang sudah komersil.

\section{DAFTAR PUSTAKA}

Abe, K., Yoji H., and Takao M. 2020. Volatile Compounds Of Fresh and Processed Garlic. Journal Experimental and Therapeutic Medicine. 19: 1585-1593.

Anggraeni, M. C., Nurwantoro., dan Setya B. M. A. 2017. Sifat Fisikokimia Roti yang Dibuat Dengan Bahan Dasar Tepung Terigu yang Ditambah Berbagai Jenis Gula. Jurnal Aplikasi Teknologi Pangan. 6(1): 52-56.

Arifiya, N., Aris P., dan I Wayan B. 2015. Analisis Perubahan Kualitas 
Pascapanen Pepaya Varietas IPB9 Pada Umur Petik yang Berbeda. Jurnal Keteknikan Pertanian. 3(1): 41-48.

BPS. 2018. Statistik Hortikultura 2018. Jakarta

BPS. 2019. Statistik Hortikultura 2019. Jakarta

Borlinghaus, J., Frank A., Martin C. H. G., Ifeanyi D. N., and Alan J. S. 2014. Allicin: Chemistry and Biological Properties. Journal Molecules. 19: 12591-12618.

Choi, S., Han S C., and Young S L. 2014. Physicochemical and Antioxidant Properties Of Black Garlic. Journal Molecules. 19(2014): 16811-16823.

Dewi, N. N., I Wayan M. 2018. Nutrition Content and Antioxidant Activity of Black Garlic. International Journal of Health Science. 2(1):11-20.

Djonny, M. 2018. Pengaruh Waktu Fermentasi Daun Nilam Menggunakan Rhizopus sp. Terhadap Rendemen Minyak Nilam. Prorosiding Seminar Nasional Pertama Sinergitas Multidisiplin Ilmu Pengetahuan dan Teknologi. Universitas Kristen Indonesia Paulus Makasar.

Engelen, A. 2018. Analisis Kekerasan, Kadar Air, Warna, dan Sifat Sensori Pada Pembuatan Keripik Daun Kelor. Journal of Agritech Science. 2(1): 10-15.

Eyupoglu, O E. 2019. Antioxidant Activities, Phenoloc Contents and Electronic Nose Analysis Of Black Garlic. International Journal of Secondary Metabolite. 6(2): 154161.

Handayani, S N., Lidya C B., Diana P A., dan Hesti N P. 2018. Isolasi
Senyawa Polifenol Black Garlic dan Uji Toksisitasnya Terhadap Larva Udang (Artemia salina Leach). Jurnal Ilmu Kefarmasian Indonesia. 16(2): 145-149.

Indiarto, R., Nurhadi B., dan Subroto E. 2012. Kajian Karakteristik Tekstur (Texture Profile Analysis) dan Organoleptik Daging Ayam Asap Berbasis Teknologi Asap Cair Tempurung Kelapa. Jurnal Teknologi Hasil Pertanian. 5: 106116.

Kang, O. J. 2016. Physicochemical Characteristics of Black Garlic After Different Thermal Processing Steps. Journal Nutrition Food Science. 21(4): 348-354.

Kimura, S., Tung Y., Pan M., Su N., Lai Y., and Cheng K. 2017. Black Garlic: A Critical Review of Its Production, Bioactivity, and Application. Journal of Food and Drug Analysis. 25(1): 62-70.

Lindani, A. 2016. Perbandingan Pengukuran Kadar Air Metode Moisture Analyzer dengan Metode Oven Pada Produk Biskuit Sandwich Cookies di PT Mondelez Indonesia Manufacturing. Skripsi. Fakultas Teknologi Pertanian. Institut Pertanian Bogor. Bogor.

Lund, M. N., and Colin A. R. 2017. Control of Maillard Reaction in Foods: Strategies and Chemical Mechanisms. Journal of Agricultural and Food Chemistry. 6(5): 4537-4552.

Miladulhaq, M. 2018. Perubahan Sifat Fisikokimia Selama Pengolahan Bawang Putih Tunggal Menjadi Bawang Hitam Menggunakan Rice Cooker. Skripsi. Fakultas Teknologi Pertanian. Institut Pertanian Bogor. Bogor. 
Nassur, R. C. M. R., Eduardo V. B. V. B., and Francisco V. R. 2017. Black Garlic: Transformation Effect, Characterization and Consumer Purchase Intention. Journal Comunicata Scientiae. 8(3): 444451.

Nelwida., Berliana., dan Nurhayati. 2019. Kandungan Nutrisi Black Garlic Hasil Pemanasan dengan Waktu Berbeda. Jurnal Ilmiah Ilmu-Ilmu Peternakan. 22(1): 53-64.

Nilasari, O. W., Wahono H. S., dan Jaya M. M. 2017. Pengaruh Suhu dan Lama Pemasakan Terhadap Karakteristik Lempok Labu Kuning (Waluh). Jurnal Pangan dan Agroindustri. 5(3): 15-26.

Nugraha, A. P., Sang N. L. A., Melati A. P., Nandya N., dan Nur R. K. 2018. Rancang Bangun Mesin Pengeringan CAMION untuk Meningkatkan Pendapatan Usaha Bawang Hitam Pada UKM WIKISCHOOL. Jurnal Pengabdian Masyarakat J-Dinamika. 3(2): 8595.

Safithri. 2004. Aktivitas Antibakteri Bawang Putih (Allium sativum) terhadap Bakteri Mastitis Subklinis Secara In Vitro dan In Vivo Pada Ambing Tikus Putih (Rattus novergicus). Tesis. Sekolah Pascasarjana IPB: Bogor.

Tsao, S.M. and Yin., M. C. 2001. In-vitro Antimicrobial Activity of Four
Diallyl Sulphides Occuring Naturally in Garlic and Chinese Leek Oils. Journal Medical Microbial. 50(7): 646-649.

Sun, Y., and Weidong W. 2018. Changes in Nutritional and Bio-Functional Compounds and Antioxidant Capacity During Black Garlic Processing. Journal Food Science Technology. 55(2): 479-488.

Widianto, D., Ajeng D. P., dan Sri W. 2013. Perbaikan Proses Fermentasi Biji Kakao Kering Dengan Penambahan Tetes Tebu, Khamir, dan Bakteri Asam Asetat. Jurnal Teknosains. 3(1): 38-44.

Yuan, H., Linjuan S., Min C., and Jun W. 2016. The Comparison of the Contents of Sugar, Amadori, and Heyns Compounds in Fresh and Black Garlic. Journal Food and Science. 00(0): 1-7.

Zhafira, R. 2018. Pengaruh Lama Aging Terhadap Sifat Fisik, Kimia, dan Aktivitas Antioksidan Produk Bawang Hitam Lanang. Jurnal Pangan dan Agroindustri. 6(1): 3442.

Zhang, X., Ningyang L., Xiaoming L., Pengli L., and Xuguang Q. 2015. Effects Of Temperature On The Quality Of Black Garlic. Journal Science Food Agricultural. 2016(96): 2366-23372. 